\section{The influence of open innovation on domestic sales in Brazilian industry: an analysis of the Innovation Survey 2014 based on structural equation modeling}

\author{
Fábio Hiroshi Tomoyose ${ }^{1,+(1)}$ \\ ${ }^{1}$ Universidade Municipal de São Caetano do Sul, São Caetano do Sul, SP, Brazil \\ Isabel Cristina dos Santos ${ }^{2, \Omega(\mathbb{D}}$ \\ ${ }^{2}$ Universidade Municipal de São Caetano do Sul, São Caetano do Sul, SP, Brazil \\ Ana Cristina de Faria $3, ¥$ (i) \\ ${ }^{3}$ FEA/USP - São Paulo, SP, Brazil
}

\begin{abstract}
This research analyzes the influence of open innovation strategy on the participation of innovations in the context of domestic sales in the Brazilian industrial sector. To perform this analysis, available data were extracted from the PINTEC 2014 Innovation Survey. In applying structural equation modeling (SEM), we found that open innovation has a direct and positive influence on the sales of new products and services in the domestic market, albeit with a modest effect. The same analysis was applied to the relationship between open innovation and domestic sales, which was found to be mediated by the impacts caused by innovation. In other words, open innovation influences the participation of innovations in domestic sales, both directly and indirectly. Besides verifying the relationship among the concepts presented in this study, it was possible to estimate their effects and make a realistic contribution to the debate, emphasizing that innovation, despite being an essential condition, is not sufficient to generate strong impacts on domestic sales, according to PINTEC 2014 respondents. To achieve high impacts, it is necessary to continuously promote and support innovation for the generation of growth.
\end{abstract}

Keywords: Domestic Sales. Innovation Survey. PINTEC 2014. Open Innovation. Structural Equation Modeling.

\section{INTRODUCTION}

In recent decades, innovation has been a subject of interest to trainers in public policy, researchers, entrepreneurs, and society as a whole. It is a multidisciplinary theme that involves ways of seeing the world, competitiveness, globalization, socioeconomic aspects, the environment, science, and technology (TIDD; BESSANT; PAVITT, 2001; CAPPELLI; CZARNITZKI; KRAFT; 2014; PERVAN; ALANSAARI; XU, 2015).

The transformation of media and information resources, influenced by advances in science and technology and by innovations in products, services, and processes, occurs quickly and continuously, and it brings a growing need to promote changes in the way organizations define their strategies (BUENO; BALESTRIN, 2012). In the words of Bueno 
and Balestrin (2012, p. 517), "one of the elements of notable evolution affects the way companies conduct the stage of research and development (R\&D) of new products, services, processes and business models."

In this context, the processes of innovation adopted by companies have been the object of studies at national and international level, because they are associated with the multidisciplinary nature of innovation and the ability to innovate (BUENO; BALESTRIN, 2012; HAUSMAN; JOHNSTON, 2014; CAPPELLI; CZARNITZKI; KRAFT; 2014; PERVAN; AL-ANSAARI; XU, 2015). Dereli, Durmusoglu, and Daim (2011) argue that companies should define strategies that accompany the dynamics of innovation to remain economically sustainable and competitive and to continuously create value for stakeholders.

Among the strategies adopted by organizations to innovate, we find relations of cooperation between companies and agents external to them, under the umbrella of the practice of open innovation (OI) (CHESBROUGH, 2003; GASSMANN; ENKEL; CHESBROUGH, 2010; BUENO; BALESTRIN, 2012; SAEBI; FOSS, 2015). OI involves relationships of collaboration in R\&D with the following parties: clients or consumers; suppliers; other companies of the group; consulting firms, universities, and research institutes; centers of professional training and technical assistance; institutions of tests and certifications; and even competitors (a process known as "coopetition") (OECD, 2005; PINTEC, 2014a,b,c).

On adoption of the strategy of OI, companies expect benefits: for example, cost reduction in the innovation process, reduction of the timeline for launching new products, reduction of the risk of failure, and increase in the capacity for innovation (CHESBROUGH, 2003; GASSMANN; ENKEL; CHESBROUGH, 2010).

Companies expect OI to contribute to the quality of products; to expand their portfolio; to maintain, expand, and open markets; to increase the capacity and flexibility of production; to reduce production and labor costs; to reduce consumption of raw materials, energy, and water; and to reduce environmental impacts (OECD, 1997; CHENG; HUIZINGH, 2014; PINTEC, 2014a,b,c; FREDERIKSEN; KNUDSEN, 2017). Most of all, they expect OI to result in greater participation of innovations in sales (OECD, 1997; OECD, 2005; KOSTOPOULOS et al., 2011; PINTEC, 2014a,b,c; TERRA; BARBOSA; BOUZADA, 2015).

In this context, the question we need to answer in this article is: What is the influence of OI strategy, and what is the participation of innovations in domestic sales of industrial activities in Brazil? In order to answer this research question, the study analyzes the influence of OI strategy in the participation of innovations in domestic sales of industrial activities in Brazil. It is a descriptive study, with a quantitative approach, that uses analysis of secondary data from the PINTEC Innovation Survey (2014c) and adopts structural equation modeling (SEM) through the method of estimation of partial least squares (PLS-PM).

\section{Theoretical Platform}

In this section we conduct a literature review, describing the concepts of OI, the impacts caused by innovation, and the participation of innovations in domestic sales.

\subsection{OPEN INNOVATION (OI)}

Innovation is a business imperative, particularly for firms operating in competitive environments, who are more exposed to the speed of change and reductions in costs and product life cycles; this demands efforts on their part that go beyond isolated actions and involve collaboration or partnerships in innovation processes with external agents (CHESBROUGH, 2003; DERELI; DURMUSOGLU; DAIM, 2011; BUENO; BALESTRIN, 2012).

As Tidd, Bessant, and Pavitt (2001) highlighted, the process of innovation for businesses is not an easy task, because it involves resources, costs, time, and risk of failure, although 
BBR

16,3

this can be minimized through cooperation with external partners. A process that adopts a combination of internal and external knowledge for the generation of innovations in products, services, or processes (i.e., collaboration, exchange, or sharing knowledge with one or more partners outside the company) is called OI (CHESBROUGH, 2003; GASSMANN; ENKEL; CHESBROUGH, 2010; BUENO; BALESTRIN, 2012; SAEBI; FOSS, 2015).

According to Chesbrough (2003), Gassman, Enkel, and Chesbrough (2010), and Pires, Teixeira, and Hastenreiter Filho (2012), the objective of companies in the adoption of OI is to accelerate the process of innovation and to reduce costs, time to market, and the risks inherent in the process itself. Nevertheless, as the same authors emphasize, it is necessary for companies, in addition to the operational benefits of OI, to benefit from other strategies, such as the combination of projects or technologies that are already in use at any given moment with the technologies of external agents involved in the innovation process, so that new opportunities or innovations are generated.

OI breaks the paradigm of horizontal innovation strategies, i.e., isolated initiatives in $\mathrm{R} \& \mathrm{D}$ that demand high investments, are subject to the risk of failure, and become obsolete even before project completion (CHESBROUGH, 2003). As Kostopoulos et al. (2011) claim, the higher the level of participation or business collaboration with suppliers, customers, competitors, universities, and research institutes in the innovation process, the greater its absorption capacity and management of external expertise.

For the European Commission (1996, apud OECD, 1997), there are two powerful elements that an innovative company should have and combine: (a) the strategic element related to predictability (CI-RONG; CHE-JU, 2015) and to the assimilation of technological and economic information, and (b) the organizational element related to risk management and internal and external cooperation.

In relation to the benefits promoted by the adoption of OI, the expectation is that it will result in innovations in products, services, or processes that are capable of influencing the participation of companies in markets, reducing operating costs, increasing production capacity, increasing sales, and contributing to issues related to the environment, such as reducing the consumption of energy and water and a reduction of environmental impacts (OECD, 1997; OECD, 2005; CHENG; HUIZINGH, 2014; PINTEC, 2014a,b,c; CAPUTO et al., 2016).

Given this context, and on the basis of the assumptions made, it is possible to advance the following hypotheses:

H1 - OI influences directly and positively the impacts caused by innovation.

$\mathbf{H 2}$ - OI influences directly and positively the participation of innovations in domestic sales.

In this study, OI is considered as a determinant of impacts caused by innovation in products, markets, processes, and other areas (the environment, health and safety, regulations and standards), as well as a determinant of participation of innovations in sales (i.e., the percentage participation of new or substantially improved products in terms of total domestic sales).

\subsection{IMPACTS OF INNOVATION (II)}

The efforts made by companies to promote innovations, such as in products, services, processes, or business models, would not make any sense in the absence of purposes or objectives to be reached (JANEIRO; PROENÇA; GONÇALVES, 2013; HAUSMAN; JOHNSTON, 2014). Thus, it is possible to affirm that, on the basis of the perceptions of decision-makers and their wishes for the success of the venture, the key drivers of actions 
directed toward innovation have been established as purposes or goals (CASSON, 2005; ALONSO; LERCHUNDI; PERES, 2016).

The expectation is that the process of innovation adopted will result in products, services, processes, or innovative business models, i.e., they are new to the market and capable of generating value for consumers, users, and entrepreneurs, they have added value, and they provide benefits related to cost reduction, increased participation in sales, preservation of the environment, and other socioeconomic aspects (OECD, 1997; OECD, 2005; CHENG; HUIZINGH, 2014; PINTEC, 2014a, b, c; FREDERIKSEN; KNUDSEN, 2017).

Research organizations, the autonomous research consultancy firms that establish relationships between innovations and organizational performance, whether at the operational, economic, or financial level (RUBERA; DROGE, 2013; KLINGENBERG et al., 2013; TERRA; BARBOSA; BOUZADA, 2015), play an important role in this relationship for decision-makers, trainers in public policy, investors, academics, and society (OECD, 1997; OECD, 2005; KLINGENBERG et al., 2013; JACOSKI et al., 2014; PINTEC, 2014a).

The Innovation Survey (PINTEC, 2014a, p. 7) is based on the Oslo Manual (OECD, 1997; OECD, 2005) and is carried out by IBGE, the Brazilian Institute of Geography and Statistics (2017), with the support of the MCTI (Ministry of Science, Technology and Innovation). The survey is one of the initiatives undertaken by the Brazilian government to find out "the innovative activities developed in industrial and service companies, in order to accompany its evolution in time." PINTEC is applied nationally and covers all sectors of the Brazilian economy, which reflects the importance of innovation for the country (PINTEC, 2014).

In accordance with the Oslo Manual (OECD, 2005), one of the most important indicators to be considered in studies of innovation is the business performance of those organizations that have deployed innovation to some degree. In this sense, the Oslo Manual (OECD, 2005 , p. 79) suggests the exploration of aspects that capture the effects of innovation in their economic goals. Any evaluation should take into account whether the innovations fulfilled any of the following functions:

a. replaced products that become obsolete;

b. introduced new products to the company's portfolio;

c. contributed to products aligned with environmental issues;

d. were able to increase the market share of the company;

e. contributed to the expansion of the company's activities (i.e., in international markets or through new consumers in the domestic market);

f. brought improvements in productive activities;

g. contributed to a reduction in production costs;

h. brought improvements in product quality;

i. contributed to improving labor activities; or

j. brought improvements in products that reduced impacts on the environment.

The indicators suggested by the Oslo Manual (OECD, 2005) and adopted by PINTEC (2014a,b,c) share the assumption that impacts of innovation (II) must also serve a purpose. This purpose, as highlighted in the Oslo Manual (OECD, 2005), refers to the participation of innovations in sales. Given this context, and on the basis of the assumptions made about OI and II, the following hypotheses can be proposed:

H3 - The impacts caused by innovation directly and positively influence the participation of innovations in domestic sales.

H4 - The impacts caused by innovation represent a concept mediator of the relationship between $\mathrm{OI}$ and the participation of innovations in domestic sales. 
BBR

16,3

The concept of II is considered to be a consequence of OI and a determinant of participation of innovations in domestic sales, as well as a mediator of the relationship between OI and the participation of innovations in sales.

\subsection{Participation of InNovation in Internal Sales (PIS)}

The participation of innovations (goods and services) in internal sales (PIS) is considered a consequence of the other concepts studied in this present work: OI and II. In the vision of Terra, Barbosa, and Bouzada (2015, p. 184), "in theory, innovations in products allow the company to expand sales and increase your revenue."

Under the strategic perspective, the research carried out by Chiang and Hung (2010) in 184 manufacturers of electronic products in Taiwan shows a positive relationship between $\mathrm{OI}$ and the economic-financial performance of incremental and radical innovations in the sample. A study by Cheng and Huizingh (2014) also found a positive and significant relationship between OI and four factors related to the performance of innovations: innovation in goods and services, success of new goods and services, consumer performance, and financial performance. As suggested in the Oslo Manual (OECD, 2005, p. 82), one of the indicators that can be used to assess the effects of innovations in business performance is "the proportion of sales due to technologically new or improved products."

In the current literature regarding the management of innovation, some articles attempt to explain the relationships among variables of innovation, including the performance of innovation in goods or services, investments in R\&D efforts in innovations, and financial performance (KOSTOPOULOS et al., 2011; KLINGENBERG et. al., 2013; TERRA; BARBOSA; BOUZADA, 2015).

The research of Terra, Barbosa, and Bouzada (2015, p. 203), the objective of which was "to investigate the influence of the performance of innovations in products and processes in the financial performance of Brazilian companies in three sectors," concluded that it is not possible to affirm that the performance of innovations in products (goods or services) and processes positively influences the profitability of enterprises. According to the authors, among the companies searched, just the chemicals industry presented the greatest evidence in favor of accepting the hypotheses. However, it was not possible to confirm what impact the variation in profitability would have upon the performance of innovation (goods, services, and processes).

A study carried out in Denmark by Laursen (2011) pointed out that when customers contribute as sources of innovation in an open system, this positively influences the level of sales of innovative goods. However, as the author emphasized, this relationship is linked to the customer's level of education; the higher the level of schooling, the lower the effect on sales levels of innovative goods. Research by Rubera (2015) reveals that design and technological innovation have a negative effect on initial sales and a positive effect on the growth rate of sales. The author suggests that customers assess the technology in a utilitarian manner, i.e., in terms of the performance of the technological artifact in a particular task.

\section{Conceptual Model}

Based on the theoretical discussion of OI, II, and PIS, and on the hypotheses advanced, a conceptual model for answering the research questions is now outlined. According to Gil (2002, p. 43), "to confront the theoretical vision with data from reality, it becomes necessary to draw a conceptual model and operating system of research." Table 1 shows the synthesis of the concepts explored and their respective relationships.

Table 1 highlights the concepts to be operationalized in this research, as well as their respective definitions, relationships, and the authors who advocate them. Figure 1 shows the conceptual model resulting from the theoretical platform proposal. 


\begin{tabular}{|c|c|c|}
\hline Concept & Description & Authors \\
\hline $\begin{array}{l}\text { Open innovation } \\
\text { (OI) }\end{array}$ & $\begin{array}{l}\text { OI refers to the innovation process, or an organizational strategy, } \\
\text { that counts on internal and external collaboration and combines } \\
\text { competences to develop new products or services, processes, or } \\
\text { business models. OI aims to generate value for the business and } \\
\text { growth in the market, now or in the future. It is expected that } \\
\text { an OI strategy will positively influence a business's operational } \\
\text { or financial results. }\end{array}$ & $\begin{array}{l}\text { OECD (1997; 2005); Tidd, Pavitt, \& Bessant } \\
\text { (2001); Chesbrough (2003); Gassmann, Enkel, } \\
\text { \& Chesbrough (2010); Dereli, Durmusoglu, \& } \\
\text { Daim (2011); Kostopoulos et al. (2011); Bueno } \\
\text { \& Balestrin (2012); Pires, Teixeira, \& Hastenreiter } \\
\text { Filho (2012); Cheng \& Huizingh (2014); PINTEC } \\
\text { (2014); Saebi \& Foss (2015); Ci-Rong \& Che-Ju } \\
\text { (2015); Caputo et al. (2016) }\end{array}$ \\
\hline $\begin{array}{l}\text { Impacts of } \\
\text { innovation (II) }\end{array}$ & $\begin{array}{l}\text { II refers to the results of a given innovation process, in relation } \\
\text { to the creation of new products or services, processes, or business } \\
\text { models, with a positive influence on business performance, such } \\
\text { as reduction in production costs, improvements in quality and/ } \\
\text { or productivity, and increases in efficiency, sustainability, and } \\
\text { market growth. }\end{array}$ & $\begin{array}{l}\text { OECD (1997; 2005); Rubera \& Droge, (2013); } \\
\text { Janeiro, Proença, \& Gonçalves (2013); Cheng \& } \\
\text { Huizingh (2014); PINTEC (2014); Hausman } \\
\text { \& Johnston (2014); Terra, Barbosa, \& Bouzada } \\
\text { (2015); Frederiksen \& Knudsen (2017) }\end{array}$ \\
\hline $\begin{array}{l}\text { Participation of } \\
\text { innovations in } \\
\text { sales (PIS) }\end{array}$ & $\begin{array}{l}\text { PIS represents the sum of efforts and investments in innovation } \\
\text { and the relationship between them and sales results, taking } \\
\text { into account the scope of the defined objectives that guide the } \\
\text { innovation strategy and positively influence the sales of products } \\
\text { and/or services. The expectation is that the adoption of an OI } \\
\text { strategy can create impacts on PIS in terms of sales volumes. }\end{array}$ & $\begin{array}{l}\text { OECD (2005); Chiang \& Hung (2010); } \\
\text { Kostopoulos et al. (2011); Laursen (2011); Cheng } \\
\text { \& Huizingh (2014); Terra, Barbosa. \& Bouzada } \\
\text { (2015); Rubera (2015) }\end{array}$ \\
\hline
\end{tabular}

Source: Prepared by the authors

Figure 1 - Conceptual model

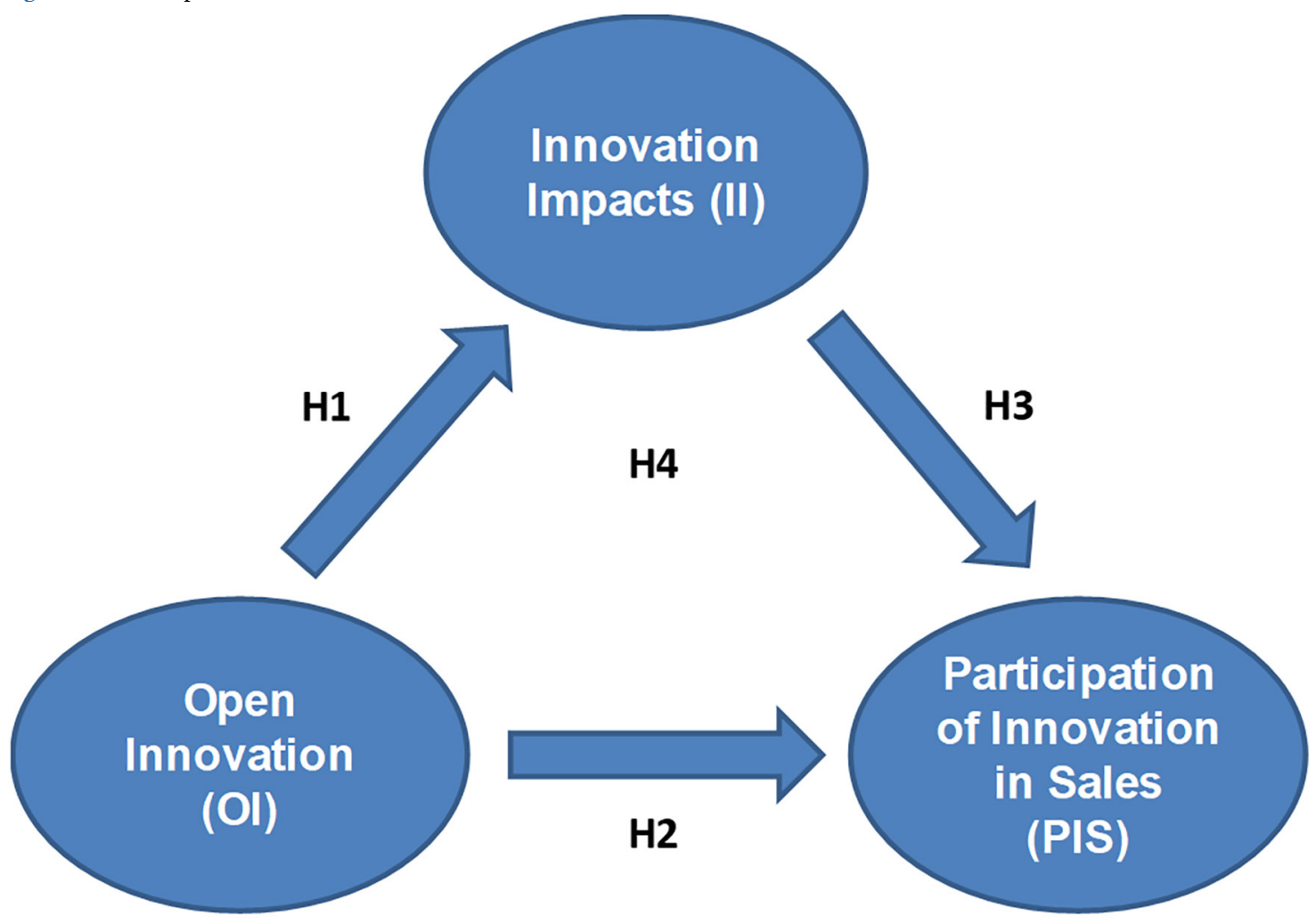

Source: Compiled by the authors

Figure 1 exhibits the three concepts of OI, II, and PIS. The arrows show the relationship or the influence of a given concept on another and represent the inferred hypotheses to be tested $(\mathrm{H} 1, \mathrm{H} 2, \mathrm{H} 3$, and $\mathrm{H} 4)$, as set out in sections 2.1 and 2.3.

In summary, the conceptual model developed assumes a direct and positive relationship between the strategy of OI and PIS (H2) and II (H1). Nevertheless, it can be inferred that II has a direct and positive relationship with PIS (H3) and constitutes a variable that mediates the relationship between the strategy of OI and PIS (H4). 


\section{Methodological Procedures}

The present study takes the form of descriptive research (GIL, 2002; HAIR Jr. et al., 2005), because it aims to describe the phenomenon of the strategy of OI and its relations with II and PIS; the study also adopts a quantitative approach (HAIR Jr. et al., 2005). In terms of technical procedures, this study is documentary research (GIL, 2002) based on the treatment of secondary data of PINTEC (2014c).

PINTEC (2014a, p. 7) is a survey conducted every three years by the Brazilian Institute of Geography and Statistics (IBGE), based on the Oslo Manual (OECD, 1997). It aims to find out about "the innovative activities developed in industrial and service companies, in order to accompany its evolution in time." The survey investigates the innovation activities of Brazilian industry in the areas of transformation, energy (electricity and gas), and certain services (PINTEC, 2014a).

The present study is based on data from the PINTEC survey carried out by the IBGE in 2014 (PINTEC, 2014c), using the period from 2011 to 2014 for the measurement of the qualitative variables and the final year (2014) to measure the quantitative variables (PINTEC, 2014a). The relevant data are contained in the following PINTEC tables (2014c):

- Table 1.1.13: Companies that implemented innovations, by degree of importance of impact caused, according to the activities of industry, the electricity and gas sector, and selected services, in Brazil 2012-2014;

- Table 1.1.14: Companies, total and those that implemented product, by percentage participation bands of new or substantially improved products in total domestic sales, according to the activities of the industry, the electricity and gas sector and the selected services - Brazil - 2014;

- Table 1.1.17: Companies that implemented innovations and their relations of cooperation with other organizations, by degree of importance of partnership, according to the activities of industry, the electricity and gas sector, and selected services, in Brazil 2012-2014.

In the PINTEC questionnaire carried out by the IBGE (2017), the items are tied to the data contained in each of the tables named 1.1.13, 1.1.14, and 1.1.17 (PINTEC, 2014c). In order to simplify the analysis of the data and to correlate the tables with their respective concepts, the coding of each questionnaire item was elaborated as in Table 2.

Table 2 shows the linking of each table to its respective concept, as well as the details relevant to each table, the corresponding items of the PINTEC questionnaire (2014a, b, c), the synthesis of the items contained in the questionnaire, and the encoding of each item for the purposes of simplification, identification, and subsequent analysis.

In relation to PINTEC table 1.1.14, it should be emphasized that the questionnaire items $85,86,87$, and 88 (PINTEC, 2014b) do not make direct reference to the percentage share of innovations in domestic sales. The results represent the frequency of answers divided into three ranges: less than $10 \%, 10 \%$ to $40 \%$, and more than $40 \%$ (PINTEC, 2014a, b, c). In other words, these are qualitative variables.

In this study, the data in PINTEC tables 1.1.13, 1.1.14, and 1.1 .17 were treated in such a way that they did not lose their original values and meanings, and a scale from $0 \%$ to $100 \%$ was applied in relation to each variable present to indicate the performance of each sector as defined by the CNAE, the National Classification of Economic Activity. The criterion adopted for PINTEC tables 1.1.13 and 1.1.17 is given in the following equation:

$$
V=\frac{A+M}{T} \times 100
$$

where $\mathrm{V}=$ the variable that indicates the performance of a particular industry in relation to the item to be measured; $\mathrm{A}=$ the quantity of assessments with a high degree of importance, 
Table 2 - Simplification and integration of items to be analyzed

\begin{tabular}{|c|c|c|c|c|c|}
\hline $\begin{array}{l}\text { Tables on } \\
\text { PINTEC } \\
(2014)\end{array}$ & Concept & Aspects considered & $\begin{array}{l}\text { \# Item on the } \\
\text { Questionnaire }\end{array}$ & $\begin{array}{l}\text { Table Item (Questionnaire } \\
\text { synthesis) }\end{array}$ & Item Code \\
\hline \multirow{15}{*}{1.1 .13} & & \multirow{2}{*}{ Product } & 93 & $\begin{array}{l}\text { Product quality improvement (good or } \\
\text { service) }\end{array}$ & V260 \\
\hline & & & 94 & $\begin{array}{l}\text { Increasing the range of products offered } \\
\text { (good or service) }\end{array}$ & V264 \\
\hline & & \multirow{3}{*}{ Market } & 95 & $\begin{array}{l}\text { Maintenance of the participation of the } \\
\text { company in the market }\end{array}$ & V268 \\
\hline & & & 96 & Increasing company's market share & V272 \\
\hline & & & 97 & Opening of new markets & V276 \\
\hline & & \multirow{7}{*}{ Process } & 98 & Increase in production capacity & V280 \\
\hline & & & 99 & Increase in production flexibility & V284 \\
\hline & \multirow{8}{*}{$\begin{array}{l}\text { Impacts of } \\
\text { Innovation on }\end{array}$} & & 100 & Reduction in the production costs & V288 \\
\hline & & & 101 & Reduction in the working costs & V292 \\
\hline & & & 102 & $\begin{array}{l}\text { Reduction in the consumption of raw } \\
\text { materials }\end{array}$ & V296 \\
\hline & & & 103 & $\begin{array}{l}\text { Reduction in the consumption of } \\
\text { energy }\end{array}$ & V300 \\
\hline & & & 104 & Reduction in the water consumption & V304 \\
\hline & & \multirow{3}{*}{ Other } & 105 & Reduction in the environmental impacts & V312 \\
\hline & & & 106 & $\begin{array}{l}\text { Improvement of the control of health } \\
\text { and safety aspects }\end{array}$ & V316 \\
\hline & & & 107 & $\begin{array}{l}\text { Adjustment to standard rules and } \\
\text { regulations }\end{array}$ & V320 \\
\hline \multirow{3}{*}{1.1 .14} & \multirow{3}{*}{$\begin{array}{c}\text { Participation of } \\
\text { Innovations in } \\
\text { sales }\end{array}$} & \multirow{3}{*}{$\begin{array}{c}\text { Percentage } \\
\text { participation of new } \\
\text { products (goods } \\
\text { or services) or } \\
\text { substantially improved } \\
\text { in total domestic sales }\end{array}$} & & Less than 10 percent & V325 \\
\hline & & & & From 10 up to 40 & V327 \\
\hline & & & $0,00,0 / c_{0}$ & Over 40 percent & V329 \\
\hline \multirow{8}{*}{1.1 .17} & \multirow{8}{*}{$\begin{array}{c}\text { Open } \\
\text { Innovation }\end{array}$} & \multirow{8}{*}{$\begin{array}{l}\text { Companies that } \\
\text { have implemented } \\
\text { innovations with } \\
\text { cooperation } \\
\text { relations with other } \\
\text { organizations, by the } \\
\text { degree of importance of } \\
\text { the partnership }\end{array}$} & 135 & Clients or consumers & V430 \\
\hline & & & 136 & Suppliers & V434 \\
\hline & & & 137 & Competitors & V438 \\
\hline & & & 138 & Another company of the group & V442 \\
\hline & & & 139 & Consulting Company & V446 \\
\hline & & & 140 & Universities and Research Institutes & V450 \\
\hline & & & 141 & $\begin{array}{l}\text { Professional training centers and } \\
\text { technical assistance }\end{array}$ & V454 \\
\hline & & & 141.1 & Testing and certification institutions & V458 \\
\hline
\end{tabular}

Source: Adapted from PINTEC (2014a, b, c)

by activity of industry; $M=$ the quantity of ratings with medium degree of importance, by industrial activity; and $\mathrm{T}=$ the total number of firms that replied to the questionnaire, by industrial activity.

The transformation of the original data (A and $M$ ) into a percentage value (V) represents the level of importance attributed by a particular industry to a variable or performance, which a determined industrial activity obtained in relation to other industrial activities; this may vary between $0 \%$ and $100 \%$. The following examples extracted from tables 1.1 .13 and 1.1.17 (PINTEC, 2014c) show the reasoning:

Example 1 - Table 1.1.13 (PINTEC, 2014c):

- Industrial activity: manufacture of articles of clothing and accessories

- Total companies of that activity that have implemented innovations: 5,107 
BBR

16,3
- Total companies of that activity that have implemented innovations with the result having a high impact on the improvement of the products (goods or services): 2,435

- Total companies of that activity that have implemented innovations the result of which was a medium impact on the improvement of the products (goods or services): 1,567

From this example data, it is possible to observe that out of a total of 5,107 firms manufacturing clothing and accessories that implemented innovations, 4,002 (78.37\%) experienced improvements in products, at either a high or medium degree of impact. In terms of judging the efficiency or the performance of clothing and accessories manufacturers in the implementation of innovations for product improvement, it can be inferred that their performance was equivalent to $78.37 \%$ compared to the others.

Example 2 - Table 1.1.17 (PINTEC, 2014c):

- Industrial activity: manufacture of articles of apparel and accessories

- Total companies of that activity that have implemented innovations (goods or services): 5,107

- Total companies of that activity that have implemented innovations, with cooperative relations with universities and research institutes and a high degree of importance of partnership (goods or services): 4

- Total companies of that activity that have implemented innovations, with cooperative relations with universities and research institutes and medium degree of importance of partnership (goods or services): 10.

From this example data, it is possible to observe that out of the total of 5,107 firms in the clothing and accessories manufacturing industry that implemented innovations, only 14 $(0.28 \%)$ did so in cooperation with universities and research institutes with either a high or medium degree of importance of partnership. In terms of judging the efficiency or the performance of clothing and accessories manufacturers in their implementation of innovations in cooperation with universities and research institutes, it can be inferred that the performance improvement of this was equivalent to $0.28 \%$ in relation to other manufacturers.

The treatment of the data contained in PINTEC table 1.1.9 (PINTEC, 2014c) took into account the particularity of each variable, according to the following criteria:

$$
V_{p}=\frac{Y 1,2,3}{T} \times 1000
$$

where $\mathrm{Vp}=$ the variable that indicates the performance of a particular industry in relation to the item under measurement; $\mathrm{Y} 1=$ the quantity of ratings, in the range of participation lower than $10 \%$, of new or substantially improved products in terms of total domestic sales; Y2 = the quantity of ratings, in the range of participation of $10 \%$ to $40 \%$, of new or substantially improved products in terms of total domestic sales; Y3 = the quantity of ratings, in the range of participation greater than $40 \%$, of new or substantially improved products in terms of total domestic sales; and $\mathrm{T}=$ the total number of firms that replied to the questionnaire, by industrial activity.

The transformation of the original data present in tracks Y1, Y2, and Y3 at percentage value $\mathrm{Vp}$ indicates the performance of a particular industry in each range of participation of products (goods or services) that are new or substantially improved in total domestic sales (PINTEC, 2014c). Performance may vary between $0 \%$ and $100 \%$ in each range of participation. The example below, extracted from PINTEC table 1.1.9 (PINTEC, 2014c), demonstrates the reasoning:

Example 3 - Table 1.1.9 (PINTEC, 2014c):

- Industrial activity: manufacture of articles of apparel and accessories 
- Total companies of such activity that replied to the questionnaire: 17,582

- Total companies (Y1) of such activity, whose percentage share of innovations (goods or services) on domestic sales was less than 10\%: 152

- Total companies (Y2) of such activity, whose percentage share of innovations (goods or services) in internal sales was between 10\% and 40\%: 1,000

- Total companies (Y3) of such activity, whose percentage share of innovations (goods or services) in internal sales was greater than $40 \%: 831$.

From this example data, it is possible to observe that out of the total of 17,582 firms in the clothing and accessories manufacturing industry that responded to the survey questionnaire (PINTEC, 2014b,c), $152(0.87 \%)$ had a percentage share of innovations (goods or services) in domestic sales of less than $10 \%(\mathrm{Y} 1) ; 1,000(5.69 \%)$ had a percentage share of innovations (goods or services) in internal sales between 10\% and 40\% (Y2); and 831 (4.73\%) of the companies had a percentage share of innovations (goods or services) in domestic sales exceeding 40\% (Y3).

The criteria described in the examples for PINTEC tables 1.1.13, 1.1.14, and 1.1.17 were considered for each variable belonging to the relevant table. For statistical purposes, we adopted SEM, using the method of PLS-PM.

\section{Description ANd Analysis of Results}

Initially, the sample was analyzed using PLS-PM to check the power of the test. In theory, PINTEC (2014a,b,c) is a census; however, the data contained in tables 1.1.13, 1.1.14, and 1.1.17 are grouped by industry activities that add up to a total of 55 cases, divided into manufacturing industry, energy, and services.

In this context, the G*Power tool of Erdfelder, Faul, and Buchner (1996) (version 3.1.9.2) was required for analysis of the power of the test, with the following input parameters: (a) 55 cases; (b) an effect of 0.15 ; (c) an error $(\alpha)$ of 0.05 ; (d) two predictors; (e) test $f$; (f) statistical test for multiple linear regression; and (g) analysis a posteriori. The result was a power of 0.7049 , or a probability $\beta(1-\beta)$ of incurring a type II error.

The data analysis started with the use of SmartPLS 2.0 software (RINGLE; WENDE; WILL, 2005), in which the conceptual model presented in Figure 1 became another model, considering all the manifest variables (encoding of items), within their respective latent variables (concepts), as described in Table 2.

It should be emphasized that the relations between the latent variables and their respective manifest variables are of the reflexive type; i.e., the manifest variables share the same meaning as their respective latent variables or are caused by the latter (HAIR Jr. et al., 2005; BREI; LIBERALI NETO, 2006).

The model originally conceived had to be made more specific, because it did not show sufficient convergent validity; the average variance extracted (AVE) showed lower values than the value of 0.50 suggested by Fornell and Larcker (1981). In addition, it was found that the manifest variables associated with the impacts of innovation in processes and other areas (the environment, health and safety, regulatory and internal standards) showed negative relationships that were weak and spurious from an analytical point of view.

Figure 2 shows the adjusted model, in which the abbreviations II-1.1.13, OI-1.1.14, and PIS-1.1.17 refer to the concepts of II, OI, and PIS (internal) and their respective tables from PINTEC (2014c).

As can be seen in Figure 2, the analysis excluded the manifest variables V280, V284, V288, V292, V296, V300, V304, V312, V316, and V320 (see Table 2) associated with the impacts of innovation in process and other areas (the environment, security, and regulation), retaining the manifest variables associated with the latent variable impacts of innovation in products (goods or services) and markets (V260, V264, V268, V272, and V276). 
BBR

16,3

Figure 2 - Adjusted model

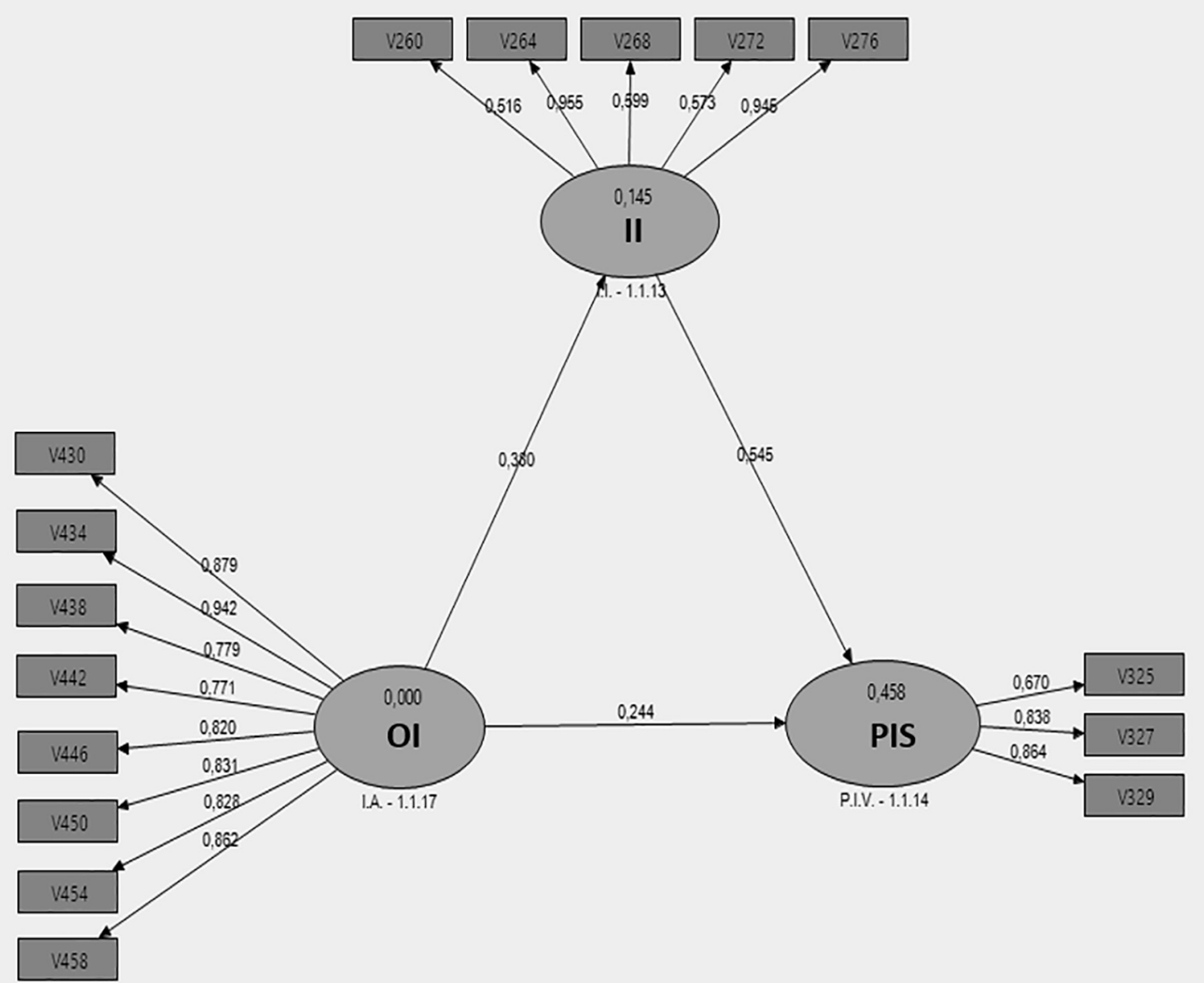

Source: Compiled by the authors, using the software SmartPLS 2.0 (RINGLE; WENDE; WILL, 2005)

The exclusion of these variables shows, contrary to expectations, that the OI strategies of cooperation or cooperation agreements adopted by Brazilian industry in the process of innovation are not, according to the perceptions of respondents to the PINTEC $(2014 b, c)$, associated with impacts of innovations in processes (production, costs, and consumption) or other areas (such as the environment, security, and regulation) in terms of achieving innovation goals. They were, however, strongly linked to the impacts of innovation in products, services, and markets, such as improvements in product quality, expansion of portfolio, and maintenance, expansion, and opening of new markets. This finding may explain the lack of convergent validity and the weak correlations (negative and spurious in the case of the manifest variables excluded) found in the original model in relation to the processes and other areas (the environment, security, and regulation).

After adjusting the model, the values listed in Table 3 were obtained for analysis of convergent validity, composite reliability, and internal consistency.

Table 3 shows that the values of AVE are above 0.50 (FORNELL; LARCKER, 1981) and that the values obtained for the analysis of composite reliability and internal consistency

Table 3 - Convergent validity, composite reliability, and internal consistency

\begin{tabular}{cccc}
\hline Latent variable & AVE (convergent validity) & Composite reliability & Cronbach's $\alpha$ \\
\hline OI -1.1 .17 & 0.7066 & 0.9505 & 0.9433 \\
II -1.1 .13 & 0.5517 & 0.8517 & 0.8353 \\
PIS -1.1 .14 & 0.6321 & 0.8359 & 0.7030 \\
Reference values & $>\mathbf{0 . 5 0}$ & $>\mathbf{0 . 7 0}$ &
\end{tabular}


are above 0.70 (NUNNALLY; BERNSTEIN, 1994). Thus, it was concluded that the adjusted model has convergent validity and can be considered reliable.

The analysis of discriminant validity was performed according to the criterion of Fornell and Larcker (1981), as recommended by Henseler, Ringle, and Sinkovics (2009), Wong (2013), and Ringle, Silva, and Bido (2014). Table 4 shows the results of the adjusted model.

Table 4 indicates that the square root of the AVE of the latent variables is higher than the correlations between them. Therefore, it is concluded that the adjusted model has discriminant validity at the level of the latent variables. Nevertheless, it is necessary to check the discriminant validity at the level of the manifest variables, as recommended by Ringle, Silva, and Bido (2014). For this, we adopted the criterion of Chin (1998), recommended by Henseler, Ringle, and Sinkovics (2009), Wong (2013), and Ringle, Silva, and Bido (2014).

Table 5 shows the loadings of the manifest variables, compared to the loadings of their counterparts, sorting themselves in their respective latent variables. The result shows that the model, at the level of the manifest variables (measurement), has discriminant validity.

In relation to the statistical significance of the structural (latent) variables and the measurement (manifest) variables in the adjusted model, we used the Bootstrapping module, SmartPLS 2.0 (RINGLE; WENDE; WILL, 2005), with 500 interactions. Significance levels were observed to be lower than $0.05(\mathrm{p}<0.05)$, i.e., $\mathrm{t}$ values were higher than 1.96 (HENSELER; RINGLE; SINKOVICS, 2009; WONG, 2013; RINGLE; SILVA; BIDO, 2014).

At the structural level, statistical significance between the latent variables was confirmed $(\mathrm{t}$ tests for IA $-1.1 .17=>\mathrm{II}-1.1 .13: 2.881 ; \mathrm{OI}-1.1 .17 \Rightarrow$ PIS 1.1.14: 2.116; II $-1.1 .13$ $=>$ PIS 1.1.14: 6.212). The first three hypotheses are therefore accepted:

Table 4 - Discriminant validity, using the criterion of Fornell and Larcker (1981)

\begin{tabular}{cccc}
\hline Latent variable & OI -1.1 .17 & II -1.1 .13 & PIS -1.1 .14 \\
\hline OI -1.1 .17 & $\mathbf{0 . 8 4 0 6}$ & & $\mathbf{0 . 7 4 2 8}$ \\
II -1.1 .13 & 0.3804 & 0.6381 & $\mathbf{0 . 7 9 5 0}$ \\
PIS -1.1 .14 & 0.4514 & \\
\hline
\end{tabular}

Source: Compiled by the authors

Table 5 - Discriminant validity, using the criterion proposed by Chin (1998).

\begin{tabular}{cccc}
\hline VM/VL & II - 1.1.13 & OI - 1.1.17 & PIS - 1.1.14 \\
\hline V260 & $\mathbf{0 . 5 1 6 2}$ & 0.0353 & 0.2248 \\
V264 & $\mathbf{0 . 9 5 5 3}$ & 0.4184 & 0.6104 \\
V268 & $\mathbf{0 . 5 9 8 9}$ & 0.0054 & 0.2033 \\
V272 & $\mathbf{0 . 5 7 2 6}$ & -0.0228 & 0.1576 \\
V276 & $\mathbf{0 . 9 4 5 0}$ & 0.4195 & 0.6781 \\
V430 & 0.5456 & $\mathbf{0 . 8 7 8 8}$ & 0.5798 \\
V434 & 0.3877 & $\mathbf{0 . 9 4 1 8}$ & 0.3959 \\
V438 & 0.3428 & $\mathbf{0 . 7 7 9 0}$ & 0.2152 \\
V442 & 0.1948 & $\mathbf{0 . 7 7 0 9}$ & 0.2266 \\
V446 & 0.0603 & $\mathbf{0 . 8 2 0 0}$ & 0.1522 \\
V450 & 0.1497 & $\mathbf{0 . 8 3 1 2}$ & 0.4549 \\
V454 & 0.1576 & $\mathbf{0 . 8 2 8 1}$ & 0.3070 \\
V458 & 0.3001 & $\mathbf{0 . 8 6 2 3}$ & 0.3481 \\
V325 & 0.3896 & 0.4180 & $\mathbf{0 . 6 7 0 1}$ \\
V327 & 0.5555 & 0.1594 & $\mathbf{0 . 8 3 7 6}$ \\
V329 & 0.5664 & 0.4517 & $\mathbf{0 . 8 6 3 5}$ \\
\hline
\end{tabular}


BBR

16,3
H1 - OI influences directly and positively the impacts caused by innovation.

$\mathbf{H 2}$ - OI influences directly and positively the participation of innovations in domestic sales.

H3 - The impacts caused by innovation directly and positively influence the participation of innovations in domestic sales.

For the fourth hypothesis, we adopted Sobel's test (SOPER, 2014) to analyze the latent variable II as a mediator in the relationship between OI and PIS. The result of the test, based on standard error (OI => II: 0.1297 and II $=>$ PIS: 0.0963 ) and the coefficient $\beta$ (OI $=>$ II: 0.380 AND II => PIS: 0.545), showed that the latent variable II is a mediator of the relationship between OI and PIS, at a significance level lower $(p<0.05)$ than one-tailed probability $(0.00463608)$ and two-tailed probability $(0.00927216)$ generated by the Sobel test. This confirms the fourth hypothesis:

H4 - The impacts caused by innovation represent a mediator concept of the relationship between the OI and the participation of innovations in domestic sales.

We also observed through of the Pearson's coefficient of determination $\left(\mathrm{R}^{2}\right)$ analysis, the relationship between OI and II, which in spite of the statistical significance of the results confirming the assumptions found in the specialized literature about this relationship (OECD, 1997; OECD, 2005; CHENG; HUIZINGH, 2014; PINTEC, 2014a, b, c; CAPUTO et al., 2016), only $14.5 \%$ of the variance of II was explained by the IA. This means that $85.5 \%$ of the variation of II can be attributed to other factors, such as qualified labor, sources of financing, closed innovation, investments, dedication, sources of information, and government support (OECD, 1997; OECD, 2005; PINTEC, 2014a,b,c).

In relation to PIS, despite the observed statistical significance confirming its dependence on II and OI, as suggested by the specialized literature (OECD, 1997; OECD, 2005; CHENG; HUIZINGH, 2014; PINTEC, 2014a,b,c; CAPUTO et al., 2016), only 45.8\% of its variation was explained by the latent variables II and OI. This means that $54.2 \%$ of the variation of PIS can be explained by other factors.

We analyzed the indicators of Stone-Geisser $\left(\mathrm{Q}^{2}\right)$ and Cohen $\left(\mathrm{f}^{2}\right)$ using the Blindfolding module of SmartPLS (RINGLE; WENDE; WILL, 2005). The indicator of $\mathrm{Q}^{2}$ showed relevance predictive of OI in relation to II (0.02), since $\mathrm{Q}^{2}$ was greater than zero (HENSELER; RINGLE; SINKOVICS, 2009; SILVA; BIDO, 2014). The endogenous variable of the PIS $\mathrm{Q}^{2}$, also greater than zero $(0.260)$, indicated the predictive quality of the exogenous variables II and OI, i.e., Q ${ }^{2}>0$ (HENSELER; RINGLE; SINKOVICS, 2009; RINGLE; SILVA; BIDO, 2014).

Finally, we analyzed Cohen's indicators $\left(\mathrm{f}^{2}\right)$ of endogenous latent variables II and PIS, with results of 0.391 and 0.283 , respectively. This means that $\mathrm{OI}$ is capable of contributing with a great effect (WONG, 2013) the coefficient of determination $\left(\mathrm{R}^{2}\right)$ of the endogenous latent variable II, as well as contributing with an average effect (WONG, 2013) the coefficient of determination $\left(\mathrm{R}^{2}\right)$ of the endogenous latent variable of PIS. Nevertheless, II, as a latent exogenous variable, contributes with an average effect (WONG, 2013) to the Pearson coefficient of determination $\left(\mathrm{R}^{2}\right)$ of the endogenous latent variable of PIS.

Given the convergent validity, discriminant validity, and reliability of the adjusted model, the confirmation of hypotheses $\mathrm{H} 1, \mathrm{H} 2, \mathrm{H} 3$, and $\mathrm{H} 4$, and the analysis of the explanatory power of the concepts, their predictive validity, and the magnitude of the relationships between them, it can be argued that the proposed model is reliable and valid. In this sense, it was possible to verify that OI directly and positively influences PIS. A variation of one unit in the performance of OI therefore, represents an increase of 0.244 in PIS.

The results allowed the estimation of the effect of OI on the impacts caused by innovation in goods, services, and markets. It is estimated that the variation of one unit in OI can cause an increase of 0.380 in II. It is also worth noting that the direct and positive influence 
of II on PIS, which estimates the variation of one unit in II, represents an increase of 0.545 in PIS.

Nevertheless, hypothesis H4 accepts that II is a mediator construct of the relationship between OI and PIS, estimating that the variation of one unit in OI can cause an indirect and positive effect of $0.207(0.380 \times 0.545)$ in PIS. In summary, the variation of one unit in OI would represent a total increase of 0.451 in PIS, with a direct and positive effect of 0.244 (OI $=>$ PIS) and an indirect and positive effect of 0.207 (OI $=>I I=>P I S)$. The next section presents the conclusions that can be drawn from these findings.

\section{Conclusions}

Based on the theory that guided the design of this research and the results that shed light on its inferences and assumptions, the research question has been answered. It can be concluded that OI directly and positively influences PIS, and it is estimated that a variation of one unit in OI involves a variation of 0.244 in PIS. Despite evidencing the relationship between OI and PIS that confirms the assumptions in the literature (CHIANG; HUNG, 2010; CHENG; HUIZINGH, 2014), we found a weak relationship, which implied to assert that the variance of PIS is due to other factors, such as II also investigated.

The result of the analysis of II revealed that its relationship with PIS was direct and positive, contributing more than twice the effect $(0.545)$ found in the relationship between OI and PIS (0.244). In other words, II has greater representativeness and greater influence on PIS than OI has on PIS.

This finding can inform the decision-making of those responsible for the allocation of resources in companies, and can lead them to productive reflection on the causes or determinants of II that are not explained by the strategy of OI alone, as indicated by Pearson's coefficient of determination $\left(\mathrm{R}^{2}=14.5 \%\right)$ for II. It is therefore recommended that future studies explore other factors linked to II.

From the adjusted model, it was possible to estimate the effect of the adoption of the strategy of OI, which although it explained only $14.5 \%$ of the variability of the concept II, had a relatively significant effect of 0.38 . In this context, it is possible to conclude that the adoption of the strategy of $\mathrm{OI}$ is representative of results obtained from efforts to innovate.

It is also worth noting the role of II as a mediator in the relationship between OI and PIS. The findings of this study indicate that OI has an indirect, positive effect (0.207) on PIS. Adding the direct and indirect effects of PIS gives a total effect of 0.451 . This confir$\mathrm{ms}$ the relevance and importance of the adoption of strategies of OI, because OI is able to influence the generation of sales not only directly but also indirectly.

Nevertheless, it is concluded that, contrary to expectations, the OI strategies of cooperation or cooperation agreements adopted by Brazilian industry in the process of innovation, according to the manifest variables explored of the PINTEC (2014c), are not linked to the processes for achieving the objectives of innovation. However, they are strongly related to its purposes, such as improvements in product quality, expansion of portfolios, and maintenance, expansion, and opening of new markets. This conclusion is supported by the lack of convergent validity and the weak correlations (negative and spurious manifest variables excluded) in relation to the impacts of innovation in processes and other areas (the environment, security, and regulation), as verified in the original model.

As noted in the results, $85.5 \%$ of variation in II can be attributed to other factors, such as qualified labor, sources of financing, closed innovation, investments, dedication, sources of information, and government support. In relation to PIS, only $45.8 \%$ of variance is explained by the latent variables II and OI. This means that $54.2 \%$ of variation in PIS can be explained by other factors. 
This research has contributed to the state of the art of the concept of OI, estimating its effects on II and PIS and observing the mediation of the impacts caused by II and its relationship with OI and PIS. Moreover, the statistical significance of the results in terms of the relationships, direct and positive, between OI and II (H1), CT and PIS (H2), and II and PIS (H3), are in line with the previous specialized literature (OECD, 1997; OECD, 2005; CHIANG; HUNG, 2010; BUENO; BALESTRIN, 2012; CHENG; HUIZINGH, 2014; PINTEC, 2014; RUBERA, 2015; CAPUTO et al., 2016; FREDERIKSEN; KNUDSEN, 2017), which advocates as one of the innovation purposes the sales generation (PIS) from the efforts made to innovate, such as OI and II.

This study has some limitations. Literature about the effects of OI on II and PIS (as opposed to the relationships between them) is scarce, particularly in the context of Brazilian industrial activities. It is suggested that future studies deepen the study of the effects of OI by investigating other variables that can contribute to the explanation of variability in II and PIS.

In summary, in its estimation of their effects, this study shows that the direct influence of OI on PIS is modest; it can be inferred that the variation of PIS is not linked only to OI and that a greater effect on PIS, in terms of products and markets, comes from II. In other words, it is not enough simply to adopt a strategy of OI; it is necessary for OI to lead to II that then stimulates or influences the generation of sales to broaden PIS; thereby, giving meaning and coherence to the efforts of innovation.

\section{REFERENCES}

ALONSO, G. M.; LERCHUNDI, I. P.; PEREZ, A. M. V. An empirical study on the antecedents of knowledge intensive entrepreneurship. International Journal of Innovation and Technology Management, v. 13, n. 5, pp. 1-15, 2016.

BREI, V. A.; LIBERALI NETO, G. L. The use of the technique of Structural Equation Modeling in the area of marketing: a comparative study between publications in Brazil and abroad. RAC: Revista de Administração Contemporânea, v. 10, n. 4, pp. 131-141, 2006.

BUENO, B.; BALESTRIN, A. Collaborative innovation: an open approach in the development of new products. RAE: Revista de Administração de Empresas, v. 52, n. 5, pp. 517-530, 2012.

CAPPELLI R.; CZARNITZKI, D.; KRAFT, K. Sources of spillovers for imitation and innovation. Research Policy, v. 43, pp. 115-120, 2014.

CAPUTO, M.; LAMBERTI, E.; CAMMARANO, A.; MICHELINO, F. Exploring the impact of open innovation on firm performance. Management Decision, v. 54, n. 7, pp. 1788-1812, 2016.

CASSON, M. Entrepreneurship and the theory of the firm. Journal of Economic Behavior and Organization, v. 58, pp. 327-348, 2005.

CHENG, C. J.; HUIZINGH, E. K. R. E. When is open innovation beneficial? The role of strategic orientation. Journal of Production Innovation Management, v. 31, n. 6, pp. 1235-1253, 2014.

CHESBROUGH, H. Open Innovation: the new imperative for creating and profiting from Technology. Harvard Business School Press, Boston, MA: 2003.

CHIANG, Y.; HUNG, K. Exploring open search strategies and perceived innovation performance from the perspective of interorganizational knowledge flows. R\&D Management, v. 40, pp. 292-299, 2010.

CHIN, W. W. The partial least squares approach for structural equation modeling: modern methods for business research. London: Lawrence Erlbaum Associates, 1998.

CI-RONG, L.; CHE-JU, L. New product adoption and sales performance from the importer perspective. Industrial Marketing Management, v. 44, pp. 98-106, 2015.

DERELI, T.; DURMUSOGLU, A.; DAIM, T. U. Buyer/seller collaboration through measurement of beliefs on innovativeness of products. Computers in Industry, v. 62, n. 2, pp. 205-212, 2011.

ERDFELDER, E. FAUL, F. BUCHNER, A. GPOWER: General power analysis program. Behavior Research Methods, Instruments \& Computers, v. 28, pp. 1-11, 1996.

EUROPEAN COMMISSION. Green paper on innovation, bulletin of the European Union, Supplement 5/95, Luxembourg, 1996.

FORNELL, C.; LARCKER, D.F. Evaluating structural equation models with unobservable variables and measurement error. Journal of Marketing Research, v. 18, n. 1, pp. 39-50, 1981. 
FREDERIKSEN, M. H.; KNUDSEN, M. P. From creative ideas to innovation performance: the role of assessment criteria. Creativity and Innovation Management, v. 26, n. 1, pp. 60-74, 2017.

GASSMANN, O.; ENKEL, E.; CHESBROUGH, H. W. The future of open innovation. R \& D Management, v. 40, n. 3, pp. 213-221, 2010.

GIL, A. C. How to prepare research projects. $4^{\text {th }}$ ed. São Paulo: Atlas, 2002.

HAIR Jr., J. F.; ANDERSON, R. E.; TATHAM, R. L.; Black, W. C. Multivariate analysis of data. $5^{\text {th }}$ ed. Porto Alegre: Bookman, 2005.

HAUSMAN, A.; JOHNSTON W. J. The role of innovation in driving the economy: lessons from the global financial crisis. Journal of Business Research, v. 67, pp. 2720-2726, 2014.

HENSELER, J.; RINGLE, C. M. R. SINKOVICS R. The use of partial least squares path modeling in international marketing. Advances in International Marketing, v. 20, pp. 277-319, 2009.

IBGE. The Brazilian Institute of Geography and Statistics. Available at: <http://www.ibge.gov.br/home/>. Accessed June 2017.

JACOSKI, C. A.; DALLACORTE, C.; BIEGER, B. N.; DEIMLING, M. F. Analysis of the performance of Regional Innovation: a case study in the industry. RAI: Revista de Administração e Inovação, v. 11, n. 2, pp. 71-88, 2014.

JANEIRO, P.; PROENÇA, I.; GONÇALVES, V. C. Open Innovation: factors explaining universities as service firm innovation sources. Journal of Business Research, v. 66, pp. 2017-2023, 2013.

KLINGENBERG, B.; TIMBERLAKE, R.; GEURTS, T. G.; BROWN, R. J. The relationship of operational innovation and financial performance: a critical perspective. International Journal of Production Economics, v. 142, pp. 317-323, 2013.

KOSTOPOULOS, K.; PAPALEXANDRIS, A.; PAPACHRONI, M.; IOANNOU, G. Absorptive capacity, innovation, and financial performance. Journal of Business Research, v. 64, pp. 1335-1343, 2011.

LAURSEN, K. User-producer interaction as a driver of innovation: costs and advantages in an open innovation model. Science and Public Policy, v. 38, n. 9, pp. 713-723, 2011.

NUNNALlY, J. C.; BERNSTEIN, I. H. Psychometric theory. $3^{\text {rd }}$ ed. New York: McGraw-Hill, 1994.

OECD. Oslo Manual: Proposed Guidelines for Collecting and Interpreting Technological Innovation Data, $2^{\text {nd }}$ ed. Oslo: OECD, European Commission, Eurostat, 1997. Available at: $<$ http://www.oecd-ilibrary.org/science-and-technology/proposed-guidelines-for-collecting-and-interpreting-technological-innovation-data_9789264192263-en>. Accessed June 2017.

OECD. Oslo Manual: Guidelines for collecting and interpreting innovation data, 3rd ed. Oslo: OECD, European Commission, Eurostat, 2005. Available at: <http://www.oecd-ilibrary.org/science-and-technology/oslo-manual_9789264013100-em>. Accessed June 2017.

PERVAN, S.; AL-ANSAARI, Y.; J. XU. Environmental determinants of open innovation in Dubai SMEs. Industrial Marketing Management, v. 50, pp. 60-68, 2015.

PINTEC, 2014. Instructions for completing the questionnaire. Rio de Janeiro: IBGE, 2015. Available at: $<$ http://www.pintec.ibge.gov.br>. Accessed June 2017.

PINTEC, 2014. Questionnaire. Rio de Janeiro: IBGE, 2015. Available at: <http://www.pintec.ibge.gov.br>. Accessed June 2017.

PINTEC, 2014. Tables. Rio de Janeiro: IBGE, 2015. Available at: <http://www.pintec.ibge.gov.br/index. php?option=com_content\&view=category\&layout=blog\&id=30\&Itemid=46>. Accessed June 2017.

PIRES, A. M. B.; TEIXEIRA, F. L. C.; HASTENREITER FILHO, H. N. Collaboration in activities of research, development and innovation: the who teaches us the model of centers and networks of excellence Petrobras/Coppe UFRJ. O\&S, v. 19, n. 62, pp. 507-526, 2012.

RINGLE, C. M.; WENDE, S.; WILL, A. SmartPLS 2.0 Beta version. Available at: <www.smartpls.de> Hamburg, 2005.

RINGLE, C. M.; SILVA, D.; Bido, D. Structural equation modeling using the SmartPLS. Remark, v. 13, n. 2, pp. 54-71, 2014.

RUBERA, G. Design innovativeness and product sales' evolution. Marketing Science, v. 34, n. 1, pp. 98$115,2015$.

RUBERA, G.; DROGE, C. Technology versus design innovation's effects on sales and Tobin's Q: the moderating role of branding strategy. Journal Production Innovation Management, v. 30, n. 3, pp. 448-464, 2013.

SAEBI, T; FOSS, N. J. Business models for open innovation: Matching open innovation strategies with business model dimensions. European Management Journal, v. 33, pp. 201-213, 2015.

SOPER, D. S. Indirect mediation effect confidence interval calculator software. Available at: <http://www. danielsoper.com/statcalc>. Accessed June 2014. 
TERRA, N.M.; BARBOSA, J. G. P.; BOUZADA, M. A. C. The influence of innovation in products and processes in the performance of Brazilian companies. RAI: Revista de Administração e Inovação, v. 12, n. 3, pp. 183-208, 2015.

TIDD, BESSANT J.; J; PAVITT, K. Managing innovation: integrating technological, market and organizational change. $2^{\text {nd }}$ ed. Chichester: John Wiley \& Sons, 2001.

WONG, K. K. K. Partial least squares structural equation modeling (PLS-WITHOUT): Techniques using SmartPLS. Marketing Bulletin, v. 24, pp. 1-32, 2013. 